\title{
Hubungan Infeksi Hepatitis Virus C Kronik dengan Kualitas Hidup Pasien Penyakit Ginjal Kronik yang Menjalani Hemodialisis Reguler
}

\author{
${ }^{1}$ Otto S. Tjhie \\ ${ }^{2}$ Frans Wantania \\ ${ }^{2}$ Stella Palar
}

\author{
${ }^{1}$ Kandidat Skripsi Fakultas Kedokteran Universitas Sam Ratulangi Manado \\ ${ }^{2}$ Bagian/SMF Ilmu Penyakit Dalam RSUP Prof. Dr. R. D. Kandou Manado \\ Email: ottomediora@gmail.com
}

\begin{abstract}
Chronic kidney disease (CKD) is a pathophysiologic process with diverse etiology, resulting in a progressive decline of renal function, and generally end up with kidney failure. CKD is a clinical condition characterized by the irreversible decline in kidney function requiring renal replacement therapy such as dialysis or kidney transplantation. This study was aimed to determine the relationship between chronic hepatitis $\mathrm{C}$ virus with the quality of life of patients with CKD who underwent regular hemodialysis. This was an observational analytical study with a cross sectional design. Samples were CKD patients undergoing hemodialysis who were infected with hepatitis $C$ virus in chronic hemodialysis at Installation of Special Measures Section Prof. Dr. R. D. Kandou Hospital Manado from October to December 2015. The results showed that there were 82 people as samples. Thirtyone $(36.6 \%)$ of them were patients with CKD who were infected with chronis hepatitis C. Most samples were male as many as 54 patients (65.9\%) and 18 of them were infected with chronic hepatitis $\mathrm{C}$ virus. The age group 39-47 years was the largest age group as many as 10 patients $(33.33 \%)$. The analysis of the relationship of anti-HCV and quality of life was tested with a correlation coefficient point biserial $(p=0.327)$. Conclusion: There were no relationship between chronic hepatitis $\mathrm{C}$ virus infectionand the quality of life in patients with chronic kidney disease undergoing regular hemodialysis.
\end{abstract}

Keywords: CKD, chronic hepatitis $\mathrm{C}$ virus infection, quality of life

\begin{abstract}
Abstrak:Penyakit ginjal kronik(PGK) adalah suatu proses patofisiologis dengan etiologi yang beragam, mengakibatkan penurunan fungsi ginjal yang progresif, dan pada umumnya berakhir dengan gagal ginjal. PGK adalah suatu keadaan klinis yang ditandai dengan penurunan fungsi ginjal yang ireversibel yang memerlukan terapi pengganti ginjal berupa dialisis atau transplantasi ginjal. Penelitian ini bertujuan untuk mengetahui hubungan hepatitis virus C kronik dengan kualitas hidup pasien PGK yang menjalani hemodialisis reguler. Jenis penelitian ialah observational analitik dengan desain potong lintang. Sampel penelitian ialah pasien PGK yang menjalani hemodialisis yang terinfeksi virus hepatitis C kronik di Instalasi Tindakan Khusus Hemodialisis Bagian/SMF Ilmu Penyakit Dalam RSUP Prof. Dr. R. D. Kandou Manado periode Oktober-Desember 2015. Hasil penelitian mendapatkan jumlah sampel sebanyak 82 orang. Tiga puluh orang $(36,6 \%)$ diantaranya ialah penderita PGK yang terinfeksi hepatitis $\mathrm{C}$ kronik. Jenis kelamin terbanyak ialah laki-laki sebanyak 54 penderita $(65,9 \%)$ dan 18 diantaranya terinfeksi virus hepatitis $\mathrm{C}$ kronik. Kelompok usia 39-47 tahun merupakan kelompok usia terbanyak yaitu 10 orang (33,33\%). Hasil analisis hubungan anti-HVC dan kualitas hidup yang diuji dengan koefisien korelasi point biserial mendapatkan niai $p=0,327$. Simpulan: Tidak terdapat hubungan antara infeksi virus hepatitis $\mathrm{C}$ kronik dan kualitas hidup pada pasien PGK yang menjalani hemodialisa reguler
\end{abstract}

Kata kunci: penyakit ginjal kronik, infeksi virus hepatitis $\mathrm{C}$ kronik, kualitas hidup 
Penyakit ginjal kronik(PGK) adalah suatu proses patofisiologis dengan etiologi yang beragam, mengakibatkan penurunan fungsi ginjal yang progresif, dan pada umumnya berakhir dengan gagal ginjal. PGK adalah suatu keadaan klinis yang ditandai dengan penurunan fungsi ginjal yang irreversibel yang memerlukan terapi pengganti ginjal berupa dialisis atau transplantasi ginjal.

Di Amerika Serikat, data tahun 19951999 menyatakan insiden Penyakit ginjal kronik diperkirakan 100 kasus perjuta penduduk pertahun, dan angka ini meningkat sekitar $8 \%$ setiap tahunnya. Di malaysia, dengan populasi 18 juta, diperkirakan terdapat 1800 kasus baru gagal ginjal pertahun. Di negara-negara berkembang lainnya, insidens ini diperkirakan sekitar 40-60 kasus perjuta peduduk pertahun. ${ }^{1}$ Sedangkan kasus PGK di Indonesia tiap tahunnya cukup tinggi, mencapai 200 - 250/1 juta penduduk. ${ }^{2}$

Dialisis adalah proses pemisahan makromolekul dari ion dan senyawa dengan berat molekul rendah dalam larutan dengan memanfaatkan perbedaan tingkat difusinya melalui membran semipermeabel. ${ }^{3}$ Salah satu teknik utama yang digunakan dalam dialisis ialah hemodialisis. ${ }^{4}$ Prinsip dasar teknik hemodialisis yaitu difusi zat terlarut dan air dari plasma ke larutan dialisis sebagai respon terhadap perbedaan konsentrasi dan tekanan tertentu. Teknik ini memiliki resiko infeksi karena menggunakan akses langsung ke pembuluh darah. ${ }^{4}$

Salah satu infeksi yang dapat terjadi pada hemodialisis ialah infeksi dari virus hepatitis yang merupakan infeksi sistemik yang menyerang hati. Virus hepatitis termasuk virus hepatotropik yang mengakibatkan hepatitis A (HAV), hepatitis B (HBV), hepatitis C(HCV), hepatitis D (HDV), dan hepatitis E (HEV). Hepatitis $C$ merupakan hepatitis yang dapat ditularkan melalui hemodialisis. ${ }^{5}$ Saat ini di dunia sekitar 1 juta oramg meninggal setiap tahun karena hepatitis $\mathrm{C}^{6}$

Sehubungan dengan adanya hubungan antara virus hepatitis dengan pasien PGK, maka penulis tertarik untuk melakukan penelitian mengenai hubungan virus hepatitis dengan kualitas hidup pasien penyakit ginjal kronik yang menjalani hemodialisis reguler.

\section{METODE PENELITIAN}

Jenis penelitian yang dilakukan ialah observational analitik dengan desain potong lintang. Penelitian ini dilakukan di Instalasi Tindakan Khusus Hemodialisis Bagian/SMF Ilmu Penyakit Dalam FK UNSRAT RSUP Prof. Dr. R. D. Kandou Manado terhitung dari bulan OktoberDesember 2015.

Populasi penelitian ialah semua pasien PGK yang menjalani hemodialisis di Instalasi Tindakan Khusus Hemodialisis Bagian/SMF Ilmu Penyakit Dalam RSUP Prof. DR. R. D. Kandou Manado periode Oktober-Desember 2015. Sampel penelitian ialah pasien PGK yang menjalani hemodialisis yang terinfeksi virus hepatitis C kronik di Instalasi Tindakan Khusus Hemodialisis Bagian/SMF Ilmu Penyakit Dalam FK UNSRAT/BLU RSUP Prof. Dr. R. D. Kandou Manado periode Oktober Desember 2015.

\section{HASIL PENELITIAN}

Jumlah sampel pada penelitian ini ialah 82 orang. Tiga puluh orang $(36,6 \%)$ diantaranya ialah penderita PGK yang terinfeksi hepatitis $\mathrm{C}$ kronik dan 52 orang $(63,3 \%)$ lainnya ialah penderita PGK yang tidak terinfeksi hepatitis C kronik. Sampel diperoleh dari periode Oktober - Desember 2015 yang memenuhi kriteria inklusi dari penelitian.

Hasil penelitian menunjukkan bahwa sampel penelitian (penderita) lebih banyak berjenis kelamin laki-laki 54 penderita $(65,9 \%)$ dibandingkan dengan perempuan $28(34,1 \%)$. Delapan belas orang yang terinfeksi virus Hepatitis C Kronik berjenis kelamin laki-laki dan 12 orang yang terinfeksi virus hepatitis $\mathrm{C}$ kronik berjenis kelamin perempuan. Tiga puluh enam orang yang tidak terinfeksi virus Hepatits $\mathrm{C}$ Kronik yang berjenis kelamin laki-laki dan 16 orang yang berjenis kelamin perempuan. 
Tabel 1. Distribusi sampel berdasarkan pemeriksaaan anti-HCV

\begin{tabular}{ccc}
\hline Anti HCV & Jumlah & $\mathbf{( \% )}$ \\
\hline Positif & 30 & 36,6 \\
Negatif & 52 & 63,4 \\
Total & 82 & 100 \\
\hline
\end{tabular}

Kelompok usia 39-47 tahun merupakan kelompok usia terbanyak yaitu 10 orang $(33,33 \%)$. Terdapat masingmasing 1 orang pada kelompok umur 1320, 21-29 dan 30-38 dengan persentase $3,33 \%$. Tujuh orang $(23,33 \%)$ terdapat pada kelompok umur 48-56. Kelompok usia $57-65$ berjumlah 8 orang $(26,67 \%)$. Terdapat 2 orang $(6,67 \%)$ termasuk dalam kelompok usia 57-65 tahun.
Hasil analisis hubungan anti-HVC dan kualitas hidup yang diuji dengan koefisien korelasi point biserial dengan melihat nilai p. Penentuan nilai alpha bergantung dari tujuan dan kondisi penelitian. Untuk bidang kesehatan biasanya digunakan nilai nilai alpha sebesar 5\%. Untuk memenuhi kriteria tersebut, nilai p harus lebih kecil dari 0,05. Berdasarkan hasil pengolahan data dengan menggunaka uji koefisien korelasi point biserial, niai $\mathrm{p}$ sebesar 0.327. Hal ini menunjukkan bahwa nilai $\mathrm{p}>0.05$ sehingga dapat disimpulkan bahwa hipotesis 0 (H0) diterima yaitu : tidak ada hubungan infeksi Virus Hepatitis C Kronik dengan kualitas hidup pasien PGK yang menjalani hemodialisis reguler.

Tabel 2. Distribusi sampel berdasarkan jenis kelamin dan anti-HCV

\begin{tabular}{lccccc}
\hline \multirow{2}{*}{ Jenis kelamin } & \multicolumn{4}{c}{ Anti-HCV } & Total \\
\cline { 2 - 4 } & \multicolumn{2}{c}{ Positif } & \multicolumn{2}{c}{ Negatif } & \\
\hline Laki-Laki & 18 & $60 \%$ & 36 & $69,2 \%$ & 54 \\
Perempuan & 12 & $40 \%$ & 16 & $30,8 \%$ & 28 \\
Total & 30 & $100 \%$ & 52 & $100 \%$ & 82 \\
\hline
\end{tabular}

Tabel 3. Distribusi Sampel Berdasarkan Umur

\begin{tabular}{lcc}
\hline Umur (tahun) & Jumlah (Orang) & $\mathbf{( \% )}$ \\
\hline $13-20$ & 1 & 3,33 \\
$21-29$ & 1 & 3,33 \\
$30-38$ & 1 & 3,33 \\
$39-47$ & 10 & 33,33 \\
$48-56$ & 7 & 23,33 \\
\hline $57-65$ & 8 & 26,67 \\
$66-74$ & 2 & 6,67 \\
\hline Jumlah & 30 & 100 \\
\hline
\end{tabular}

Tabel 4. Hubungan kualitas hidup dengan anti-HCV

\begin{tabular}{cccc}
\hline Variabel 1 & Variabel 2 & $\mathrm{R}$ & $\mathrm{P}$ \\
\hline Anti-HCV & Kualitas Hidup & $\mathbf{0 , 0 5 0}$ & $\mathbf{0 , 3 2 7}$ \\
\hline
\end{tabular}

Tabel 5. Distribusi rerata kualitas hidup berdasarkan anti-HCV

\begin{tabular}{lll}
\hline Anti-HCV & Rata-rata & Std.Deviation \\
\hline Positif & 63,0471 & 19,38422 \\
Negatif & 61,1554 & 17,74649 \\
\hline
\end{tabular}


Berdasarkan Tabel diatas, dapat dilihat bahwa rata-rata kualitas hidup pasien yang terinfeksi virus hepatitis C sebesar 63,0471 dan pasien yang tidak terinfeksi sebesar 61,1554. Perbedaan rata-rata pasien dengan anti HCV positif dan negatif tidak terlalu jauh. Hal ini ikut mendukung hipotesis 0 (H0) yaitu tidak ada hubungan infeksi Virus Hepatitis C Kronik dengan kualitas hidup pasien PGK yang menjalani hemodiallisis reguler.

\section{BAHASAN}

Selama periode Oktober-Desember 2015 di SMF Ilmu pemyakit dalam Prof. DR. R. D. Kandou manado khususnya di Unit Hemodialisa didapatkan 30 orang yang terinfeksi Virus Hepatitis $\mathrm{C}$ dan 52 orang yang tidak terinfeksi. Angka ini lebih tinggi jika dibandingkan dengan penelitian sebelumnya yaitu 13 orang yang terdeteksi HCV positif.?

Berdasarkan jenis kelamin, pasien PGK yang menjalani hemodialisis dengan HCV positif memiliki distribusi pada lakilaki 18 orang $(60 \%)$ sedangkan pada perempuan sebanyak 12 orang (40\%). Perbandingan antara laki-laki dan perempuan sebesar 1,5:1. Penelitian ini selaras dengan penelitian sebelumnya yang mengatakan bahwa jenis kelamin laki-laki lebih banyak terdeteksi HCV positif daripada perempuan. ${ }^{7}$

Berdasarkan kelompok umur, pasien PGK yang menjalani hemodialisis dengan HCV positif memiliki distribusi antara umur 13-21 tahun terdapat 1 orang $(3,33 \%)$, antara umur 22-30 tahun terdapat 1 orang (3,33\%), antara umur 31-39 tahun terdapat 1 orang $(3,33 \%)$, antara umur 13 21 tahun terdapat 1 orang $(3,33 \%)$, antara umur 40-48 tahun terdapat 10 orang $(33,33 \%)$, antara umur $49-57$ tahun terdapat 7 orang $(23,33 \%)$, antara umur 58-66 tahun terdapat 8 orang $(26,67 \%)$, dan antara umur 76-84 tahun terdapat 2 orang $(6,67 \%)$. Hal ini berkorelasi dengan data yang ada bahwa jumlah pasien PGK yang menjalani hemodialisa terbanyak adalah usia diatas 40 tahun sehingga peluang untuk mengidap HVC lebih besar pada usia tersebut. ${ }^{7}$
Analisis hubungan infeksi Virus Hepatitis C dengan kualitas hidup pada pasien PGK hemodialisa reguler

Analisis hubungan infeksi Virus Hepatitis C dengan kualitas hidup pada pasien PGK hemodialisa reguler diuji dengan Point Biserial Corelation. Hasil analisis hubungan infeksi Virus Hepatitis C dengan kualitas hidup pada pasien PGK hemodialisa reguler menunjukkan tidak ada hubungan antara keduanya dengan nilai p>0,05. Pada penelitian ini tidak didapatkan hubungan.

Hal ini bertentangan dengan penelitian yang dilakukan Antoine pada tahun 2014. Penelitian yang dilakukan di Brazil ini, menemukan bahwa adanya hubungan antara infeksi virus hepatitis $\mathrm{C}$ dengan kualitas hidup pada masyarakat umum. ${ }^{8}$ Hal ini dimungkinkan karena PGK sendiri ikut memperngaruhi kehidupan pasien. ${ }^{9}$ Sehingga penelitian ini tidak mendapatkan ada hubungan antara infeksi virus hepatitis C dengan kualitas hidup pada pasien PGK yang menjalani hemodialisa reguler.

Pada saat pegambilan data kuesioner, peneliti juga meminta bantuan pada keluarga untuk ikut mengisikan lembar kuesioner tentang kualitas hidup namun harus sesuai dengan pendapat pasien, sehingga memungkinkan ada beberapa kuesioner yang terisi dengan kualitas hidup yang baik padahal jika dilihat dari segi fisik terlihat kurang baik. Hasil kuesioner tetap valid karena jawaban subyektif sesuai dengan pendapat pasien. ${ }^{10}$

Keterbatasan penelitian ini ialah kurangya data skrining pemeriksaan anti$\mathrm{HCV}$ yang berkala yang terdapat dalam rekam medik. Hal ini disebabkan oleh beberapa hal, yaitu tidak diperiksanya anti HCV secara berkala ataupun masalah penyimpanan rekam medik.

\section{SIMPULAN}

Berdasarkan hasil penelitian dan bahasan dapat disimppulkan bahwa tidak terdapat hubungan antara infeksi virus hepatitis C kronik dengan kualitas hidup pasien PGK yang menjalani hemodialisa reguler. 
Ucapan terima kasih disampaikan pada dr. B. J. Waleleng, SpPD-KGEH, dr. Cerelia Sugeng, SpPD, dr Cecilia Hendrata, SpPD, dr Audrey Amelia, Yusuf S. Tandilingtin, Regina C. Senduk, Vanessa Teiseran, Daniel Ruscianto, dan pada semua pihak yang baik secara langsung maupun tidak langsung telah menumbuhkan ide atau gagasan dalam pemikiran penulis sehingga dapat menyelesaikan artikel ini.

\section{DAFTAR PUSTAKA}

1. Suwitra K. Penyakit Ginjal Kronik. In: Sudoyo A W, Setiyohadi B, Alwi I, Simadibrata M, Setiadi S, penyunting. Buku Ajar Ilmu Penyakit Dalam (5th ed). Jakarta: Interna Publishing, 2009; p. 1035-40.

2. Ara R, Muhammad R, Triawanti. Hubungan antara adekuasi hemodialisis dan kualitas hidup pasien di RSUD Ulin Banjarmasin. ejournal: Portal Garuda, 2013.

3. Kamus Kedokteran Dorland. Jakarta: EGC, 2000; p. 986.

4. Prince S, Wilson L. Patofisiologi Vol 2. Jakarta: EGC, 2005; p. 972-6.

5. Asri Rl. Gambaran hepatitis virus pada pasien rawat inap di Bagian /SMF Ilmu Penyakit Dalam FK Unsrat/
RSUP Prof. Dr. R. D. Kandou Manado [Skripsi]. Manado: Fakultas Kedokteran Universitas Sam Ratulangi; 2012.

6. WHO. Available from: http://www. Who.Int/Mediacentre/News/Releases/ 2015/World-Hepatitis-Day/En/

7. Aruperes MI. Gambaran hepatitis virus C pada pasien penyakit ginjal kronik yang menjalani hemodialisis rutin di SMF Ilmu Penyakit Dalam Rsup Prof Dr. R. D. Kandou Manado [Skripsi]. Manado: Fakultas Kedokteran Universitas Sam Ratulangi; 2012.

8. El Khoury AC, Vietri J, Prajapati G. Health-related quality of life in patients with hepatitis $\mathrm{C}$ virus infection in Brazil. Rev Panam Salud Publica. 2014;35(3):200-6.

9. Fabrizi F, Messa P, Martin P. The unravelled link between chronic kidney disease and hepatitis C infection. New Journal of Science. 2014;2014. ID 180203.

10. Nurcahayati, Sofiana. Anlisis faktorfaktor yang berhubungan dengan kualitas hidup pasien penyakit ginjal kronik yang menjalani hemodialisis di Rumah Sakit Islam Fatimah Cilacap dan Rumah Sakit Umum Daerah Banyumas [Tesis]. Depok: Universitas Indonesia; 2010. 